\title{
Development of Preparative Chromatography for Proteomic Approach of Mycorrhizal Symbiosis
}

\author{
Tomoko Matsubara*, Takaaki Ishii \\ Graduate School of Life and Environmental Sciences, Kyoto Prefectural University, Kyoto, Japan \\ Email: "s810631049@kpu.ac.jp
}

Received 23 December 2014; accepted 27 January 2015; published 2 February 2015

Copyright (C) 2015 by authors and Scientific Research Publishing Inc.

This work is licensed under the Creative Commons Attribution International License (CC BY).

http://creativecommons.org/licenses/by/4.0/

(c) (i) Open Access

\begin{abstract}
Although mechanism of symbiosis between arbuscular mycorrhizal fungi (AMF) and host plants has been investigated by genetic analysis, very little knowledge has been obtained because genome analysis of AMF is not perfect yet. Thus, we tried to develop mass purification of proteins using preparative chromatography in order to accelerate roteomic analysis of proteins related to mycorrhizal symbiosis, such as 24 and $53 \mathrm{kDa}$ proteins. In particular, our data showed that $53 \mathrm{kDa}$ proteins would be restrictively expressed when mycorrhizal fungi and host plants were stressed. However, 24 kDa proteins, which appear to be a usable indicator for the existence of various mycorrhizal fungi, were habitually detected in not only AMF but also other mycorrhizal fungi such as ectomycorrhizal fungi (EF). Moreover, we discovered new preparative chromatographical techniques for isolation and mass purification of those proteins. We are convinced that this chromatographical technique will greatly contribute to proteomic approach of mycorrhizal symbiosis.
\end{abstract}

\section{Keywords}

24 kDa Protein, Mycorrhizal Fungi, Preparative Chromatography, Proteomic Analysis, Symbiosis

\section{Introduction}

Although importance of AMF for sustainable food production is widely known, the mechanism of AMF symbiosis is not so clear. Since AMF have been known to be multinuclear and multiform [1] and to take away cell nuclei from plant hosts [2], it is difficult to approach from genome sequence and often causes confusion in classification of species [3]. Therefore, we focused on proteomic approach for identification of proteins related to

"Corresponding author. 
mycorrhizal symbiosis, which would indicate the expression of genes in AMF. Our previous reports show that AMF [4] and orchid mycorrhizal fungi (OMF) [5] have proteins of 24 and $53 \mathrm{kDa}$ in molecular weight that are related to mycorrhizal symbiosis. These facts indicate that various kinds of mycorrhizal fungi will have similar proteins for symbiotic relationship with plants. However, now there are no useful techniques for mass purification of the proteins, which contribute to proteomic approach of mycorrhizal symbiosis.

Therefore, we examined not only separation of proteins related to mycorrhizal symbiosis in AMF and EF using SDS-PAGE techniques, but also development of new preparative chromatography for isolation and mass purification of the proteins on proteomic approach of the symbiosis.

\section{Materials and Methods}

\subsection{SDS-PAGE of Proteins}

In this experiment, we used pot-cultured bahiagrass (Paspalum notatum Flügge.) roots inoculated with and without Glomus clarum, AMF spores, such as Gigaspora albida, Gigaspora margarita and G. clarum, stocked in a refrigerator at $4^{\circ} \mathrm{C}$, and EF hyphae, such as Tricholoma matsutake (NBRC 6933) at 4,25 and $40^{\circ} \mathrm{C}$ and Rhizopogon roseolus at $25^{\circ} \mathrm{C}$ in Ebios media.

Crude proteins were extracted from $5 \mathrm{~g}$ of bahiagrass roots inoculated with and without G. clarum, approximately 5000 of AMF spores, and approximately $0.1 \mathrm{~g}$ of EF hyphae by modified methods of Shannon et al. [6]. That is, these samples were homogenized with $0.05 \mathrm{M}$ Tris buffer (pH 7.5) containing $0.05 \mathrm{M} \mathrm{NaCl}$, and then the homogenates were filtered through a cheese cloth. After ammonium sulfate were added into the liquid to $35 \%$ saturation, they were stood overnight at $4^{\circ} \mathrm{C}$. They were centrifuged at $8000 \mathrm{~g}$ for $30 \mathrm{~min}$ and then added ammonium sulfate into the supernatant to $95 \%$ saturation. After standing overnight at $4^{\circ} \mathrm{C}$, they were centrifuged at $8000 \mathrm{~g}$ for $30 \mathrm{~min}$ and then the residues were dissolved in $2 \mathrm{ml}$ of $0.005 \mathrm{M}$ Tris buffer (pH 7.0). Dialyzation was done against $0.005 \mathrm{M}$ Tris buffer $(\mathrm{pH} 8.0)$ containing $0.1 \mathrm{M} \mathrm{KCl}$ for overnight. After centrifugation at $8000 \mathrm{~g}$ for $30 \mathrm{~min}$, we obtained the supernatant with crude proteins.

To detect 24 and $53 \mathrm{kDa}$ proteins in the crude proteins, the SDS-PAGE was carried out by the methods of Laemmli [7]. Each of the crude proteins obtained from bahiagrass roots, Gi. albida, Gi. margarita, G. clarum, T. matsutake and $R$. roseolus were used, and the protein bands on the SDS-PAGE gel plates were analyzed by the iMeasure Scan software (iMeasure Inc.).

\subsection{Isolation and Mass Purification of Proteins by Chromatography}

As shown in Figure 1, we developed a new method for isolating and purifying 24 kDa protein related to mycorrhizal symbiosis from crude proteins of soybean (Glycine max) roots inoculated with Glomus intraradices and sod-cultured peach orchard soil. That is, crude proteins were extracted by modified procedures of Shannon et al. [6], and then were separated by medium pressure liquid chromatography (MPLC) with a Diol column to remove ammonium sulfate and to obtain the fractions including 24 and $53 \mathrm{kDa}$ proteins. The solvent was 0.001 $\mathrm{M}$ Tris- $\mathrm{HCl}+0.001 \mathrm{M} \mathrm{NaCl}(\mathrm{pH} 7.5)$ and the flow rate was $3 \mathrm{ml} / \mathrm{min}$. A detecter was used at $280 \mathrm{~nm}$. Moreover, we purified these proteins on gradient methods using a preparative high pressure liquid chromatograph (HPLC) with a Diol column.

\subsection{Properties of $24 \mathrm{kDa}$ Protein}

To analyze the properties of pure $24 \mathrm{kDa}$ protein related to mycorrhizal symbiosis, the protein solution was spotted on thin-layer chromatographic plates, and then various stains, such as ninhydrin, Rhodamine 6G, fluorescein, Dittmer reagent, $\mathrm{FeCl}_{2}$ and hydroxylamine chloride, were sprayed on protein spots. Then, color changes of the spots were observed.

\section{Results}

Although non-mycorrhizal bahiagrass roots have no 24 and 53 kDa proteins (Figure 2), $24 \mathrm{kDa}$ proteins were detected in all of crude proteins extracted from mycorrhizal samples (Figures 2, 3 and 4), but $53 \mathrm{kDa}$ proteins were not detected in crude proteins of T. matsutake cultured at $25^{\circ} \mathrm{C}$ (Figure 3). The $53 \mathrm{kDa}$ proteins were appeared when T. matsutake was cultured under low or high temperature stressed conditions such as $4^{\circ} \mathrm{C}$ and $40^{\circ} \mathrm{C}$ 
Roots $40 \mathrm{~g}$

$\downarrow$

Homogenized with $80 \mathrm{ml}$ of $0.001 \mathrm{M}$ Tris-HCl buffer (pH 7.5) containing $0.001 \mathrm{M} \mathrm{NaCl}$
Soils $100 \mathrm{~g}$

Shook with $200 \mathrm{ml}$ of $0.1 \mathrm{M}$ phosphate buffer (pH 7) containing $0.01 \mathrm{M}$ EDTA and $0.3 \mathrm{M} \mathrm{KCl}$

Extracted crude proteins by modified methods of Shannon et al. (1966)

Filtered the homogenates through a cheese cloth.

Added ammonium sulfate into the liquid to $35 \%$ saturation.

Stood overnight at $4^{\circ} \mathrm{C}$ and then centrifuged at $8000 \mathrm{~g}$ for $30 \mathrm{~min}$.

Added ammonium sulfate into the supernatant to 95\% saturation.

Stood overnight at $4^{\circ} \mathrm{C}$ and then centrifuged at $8000 \mathrm{~g}$ for $30 \mathrm{~min}$.

Residues were dissolved in $2 \mathrm{ml}$ of $0.005 \mathrm{M}$ Tris buffer (pH 7.0).

$\downarrow$

Removed ammonium sulfate and fractionated crude proteins using a MPLC

Column: Diol (75-200 $\mu \mathrm{m})$ (Fuji Silysia Chemical Ltd. ), $\varphi 35 \times 400 \mathrm{~mm}$

Solvent: $0.001 \mathrm{M}$ Tris- $\mathrm{HCl}+0.001 \mathrm{M} \mathrm{NaCl}(\mathrm{pH}=7.5)$

Flow rate: $3 \mathrm{ml} / \mathrm{min}, \mathrm{UV}: 280 \mathrm{~nm}$

$\downarrow$

Isolated $24 \mathrm{kDa}$ proteins using a preparative HPLC with a Diol column by gradient methods

Column: Develosil 300 Diol (Nomura Chemical Co., Ltd. ), $\varphi 10 \times 250 \mathrm{~mm}$

Solvent: 0-10 $\min 0.001 \mathrm{M}$ Tris- $\mathrm{HCl}+0.001 \mathrm{M} \mathrm{NaCl}(\mathrm{pH}=7.5)$

10-50 min 0.001 M Tris- $\mathrm{HCl}+0.001 \mathrm{M} \mathrm{NaCl}(\mathrm{pH}=6.5)$

50-60 min 0.001 M Tris- $\mathrm{HCl}+0.001 \mathrm{M} \mathrm{NaCl}(\mathrm{pH}=7.5)$

Flow rate: $0.5 \mathrm{ml} / \mathrm{min}$, Temperature: $20^{\circ} \mathrm{C}$, UV: $280 \mathrm{~nm}$

Figure 1. Procedures for the extraction and purification of proteins in roots and soils.
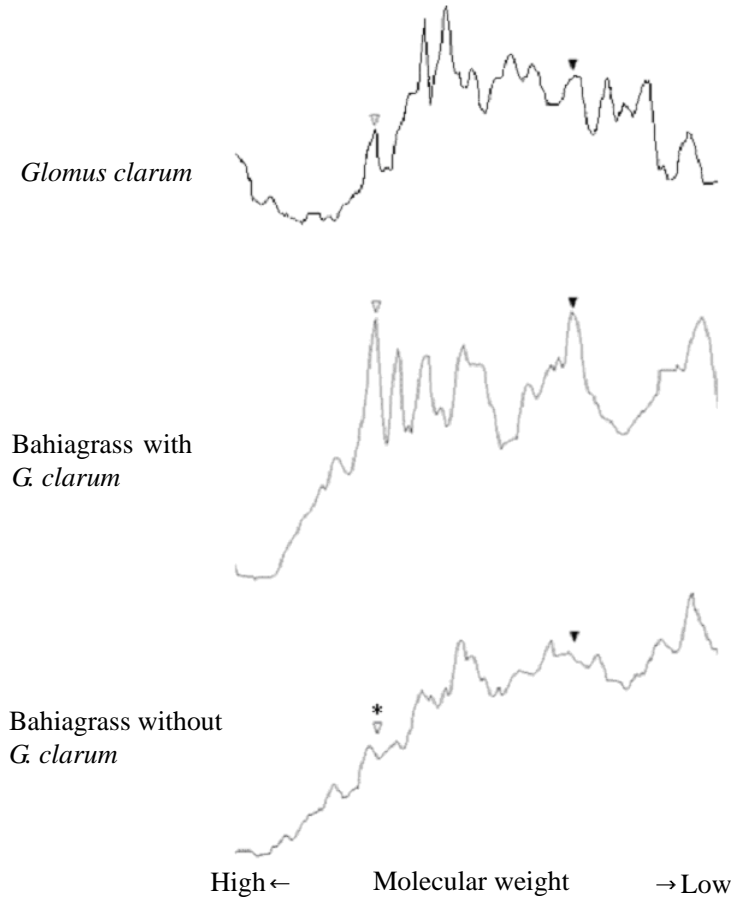

Figure 2. Densitograms of crude proteins extracted from Glomus clarum spores and inoculated bahiagrass roots. Bahiagrass roots were harvested on September 6th. White and black arrows show 53 and $24 \mathrm{kDa}$ proteins, respectively. An asterisk shows no significant peak for $53 \mathrm{kDa}$ proteins in bahiagrass without AMF. 


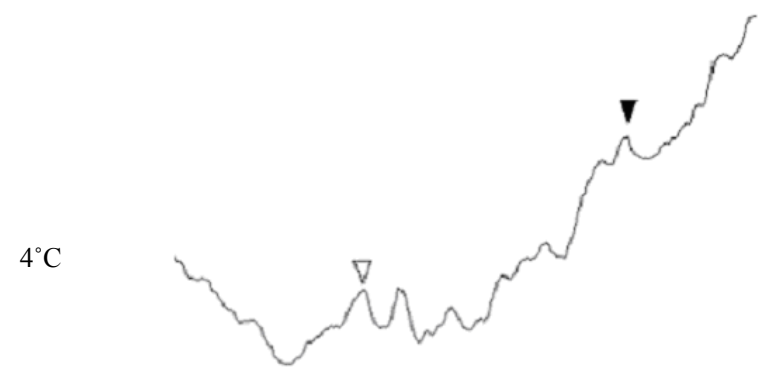

$25^{\circ} \mathrm{C}$
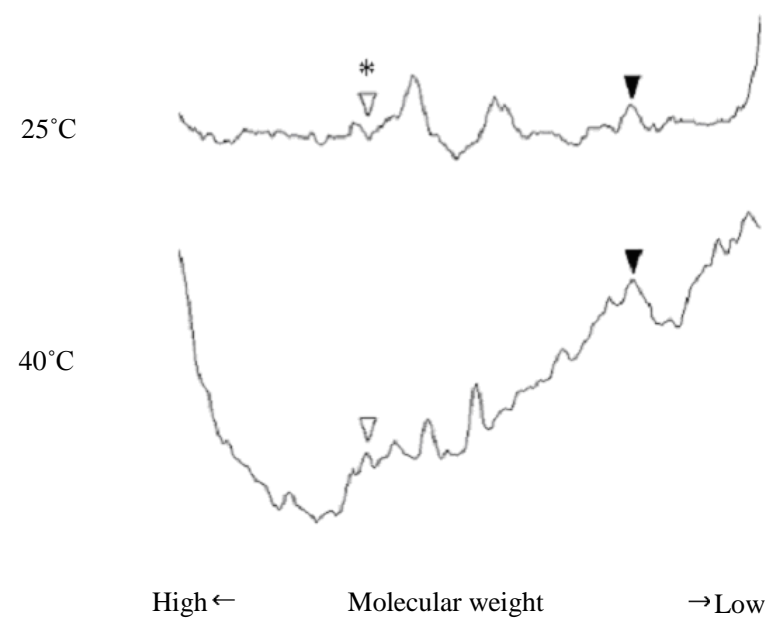

Figure 3. Densitograms of crude proteins T. matsutake at $4^{\circ} \mathrm{C}, 25^{\circ} \mathrm{C}$ and $40^{\circ} \mathrm{C}$ for 3 days. White and black arrows show 53 and $24 \mathrm{kDa}$ proteins, respectively. An asterisk shows no significant peak for $53 \mathrm{kDa}$ proteins at $25^{\circ} \mathrm{C}$.

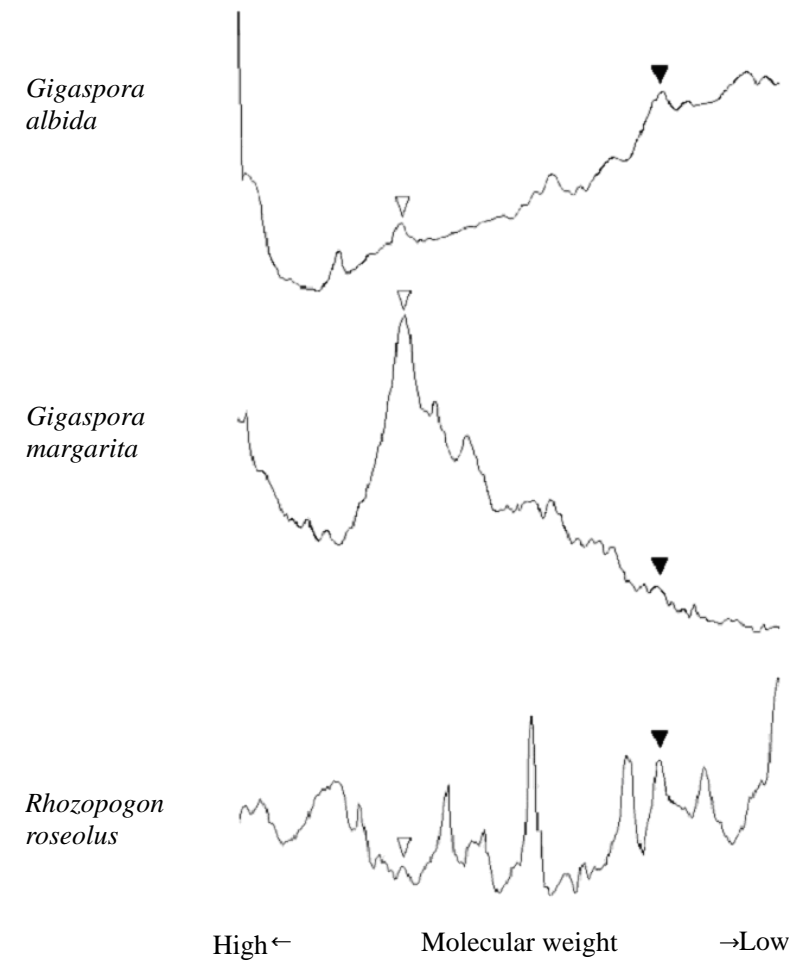

Figure 4. Densitograms of crude proteins extracted from other AMF and ectomycorrhizal fungi. White and black arrows show 53 and $24 \mathrm{kDa}$ proteins, respectively. 
(Figure 3). The $53 \mathrm{kDa}$ proteins were also detected in pot-cultured bahiagrass roots inoculated with AMF, all AMF spores stored at $4^{\circ} \mathrm{C}$ and $R$. roseolus cultured at $25^{\circ} \mathrm{C}$ (Figure 2 and Figure 4).

On mass purification of proteins, both of preparative chromatographs, MPLC and HPLC, with a Diol column were very useful for isolating and purifying great amounts of crude proteins extracted by ammonium sulfate precipitation. Moreover, a gradient method on preparative HPLC using a Diol column separated each protein in $24 \mathrm{kDa}$ protein fraction. As shown in Figure 5(a), the chromatogram of soil proteins fractionated by an isochromatic method on a preparative HPLC with a Diol column shows existence of $24 \mathrm{kDa}$ proteins as well as mycorrhizal fungi and plant roots, but it was impossible to isolate pure $24 \mathrm{kDa}$ protein (Peak 5) related to mycorrhizal symbiosis from the $24 \mathrm{kDa}$ protein fraction. The development of a gradient method on preparative HPLC, however, solved the isolation of the same or almost the same as molecular weight of proteins. Thus, it became possible to isolate the pure $24 \mathrm{kDa}$ protein (Figure 5(b) and Figure 6).

The properties of the $24 \mathrm{kDa}$ protein purified were analyzed using some kinds of stains (Table 1). That is, the detection by Rhodamine 6G showed that the $24 \mathrm{kDa}$ protein is bound with lipids. Other stains, such as fluorescein, Dittmer reagent, $\mathrm{FeCl}_{2}$ and hydroxylamine chloride, showed that the lipids were simple ones such as ester lipids, sterol lipids and non-phospholipids. The pink spot made by ninhydrin indicated the existence of peptides. Therefore, the pure 24 kDa protein was lipoproteins with ester and sterol lipids (Table 1).
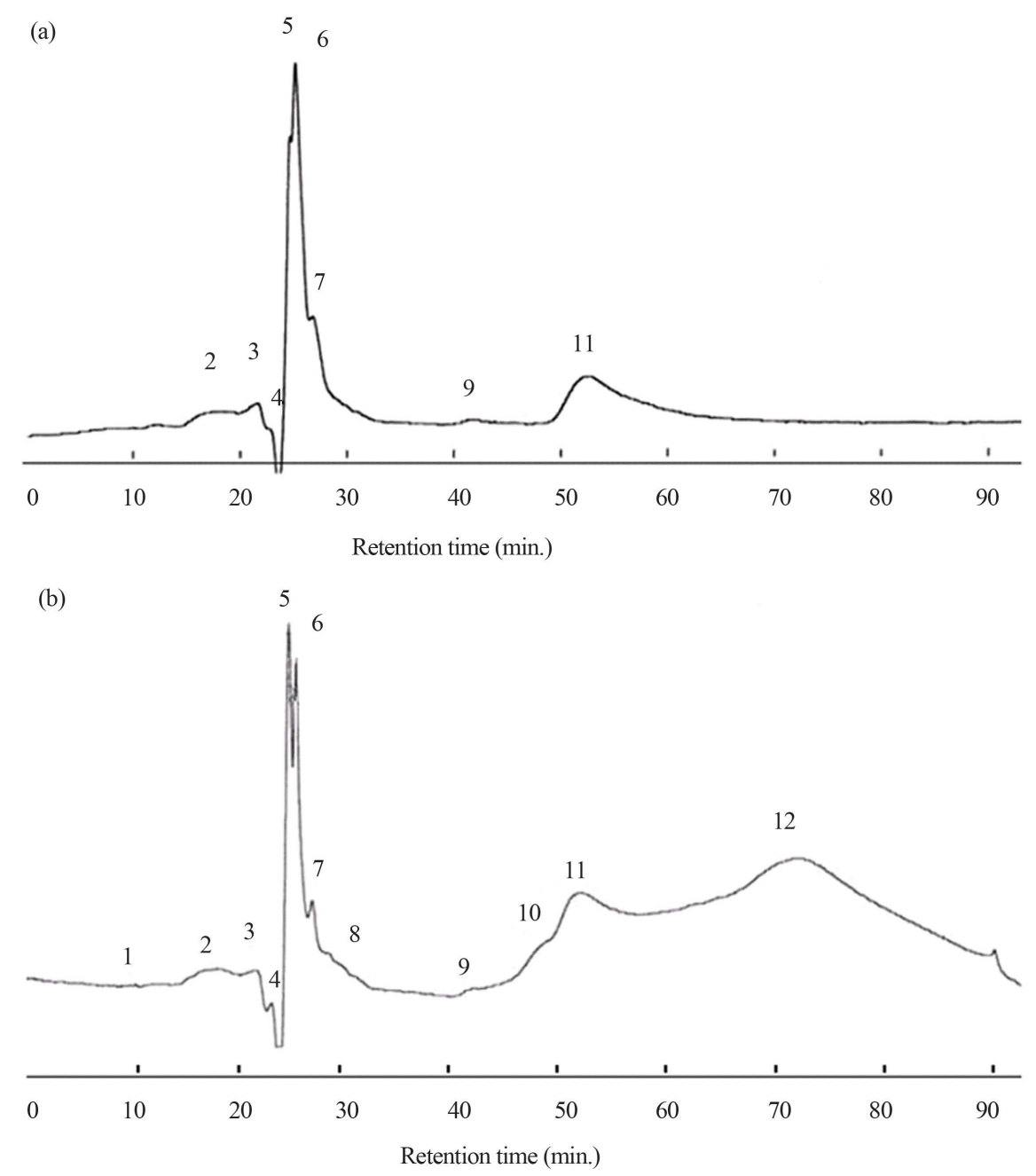

Figure 5. Chromatogram of soil proteins fractionated by HPLC. (a) Isochromatic methods Column: Develosil 300 Diol, $\varphi 10 \times 250 \mathrm{~mm}$, Solvent: $0.001 \mathrm{M}$ Tris- $\mathrm{HCl}+0.001 \mathrm{M} \mathrm{NaCl}$ (pH = 7.5), Flow rate: $0.5 \mathrm{ml} / \mathrm{min}$, Temperature: $20^{\circ} \mathrm{C}$, UV: $280 \mathrm{~nm}$; (b) Gradient methods (see in Figure 1). 


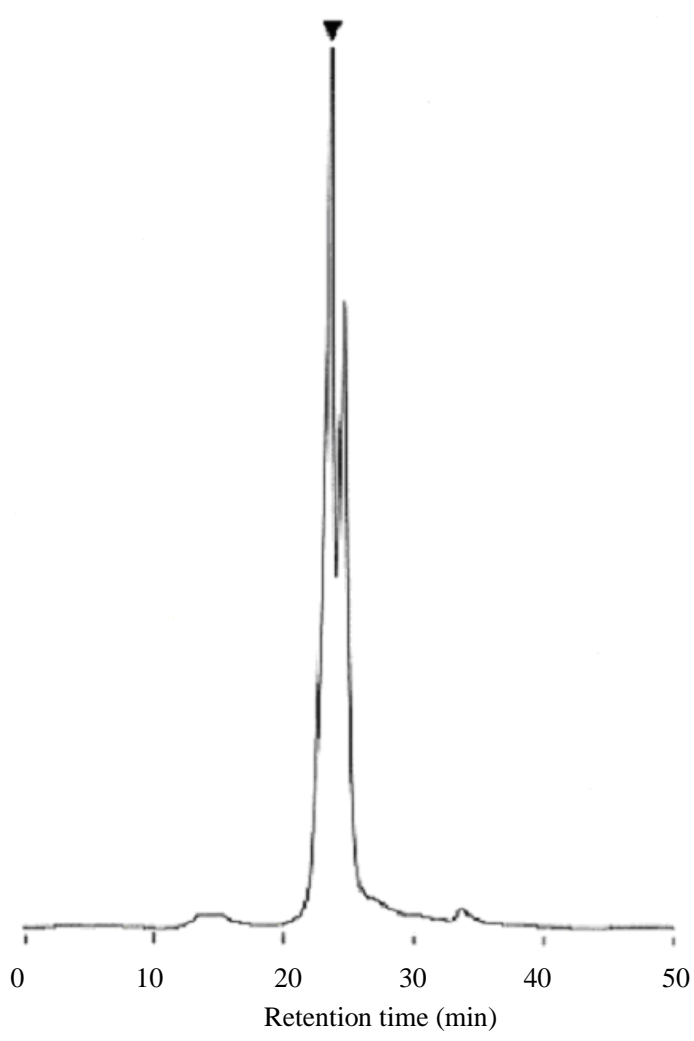

Figure 6. A chromatogram of $24 \mathrm{kDa}$ proteins of Glomus intraradices-inoculated soybean roots fractionated by gradient HPLC. Gradient methods: see in Figure 1. The black arrow shows $24 \mathrm{kDa}$ proteins in the electrophoresis with SDS plates.

Table 1. The properties of a $24 \mathrm{kDa}$ protein using some kinds of stains.

\begin{tabular}{ccc}
\hline Stains & Spot color & Decision \\
\hline Ninhydrin & Slight pink & Amino groups \\
Rhodamine 6G & Orange & Lipids \\
Fluorescein & Yellow & Simple lipids \\
Dittmer reagent & - & Non phospholipids \\
$\mathrm{FeCl}_{2}$ & Purple & Sterol lipids \\
Hydroxylamine chloride & Slight purple & Ester lipids \\
\hline
\end{tabular}

\section{Discussion}

The results of SDS-PAGE indicated that $24 \mathrm{kDa}$ proteins were habitually detected in not only AMF [3], OMF [4] and ericoid mycorrhizal fungi (unpublished), but AMF and EF used. Therefore, the proteins would be related to symbiosis between plants and mycorrhizal fungi. Furthermore, pure $24 \mathrm{kDa}$ protein, which isolated from crude $24 \mathrm{kDa}$ proteins by preparative chromatography, was revealed to be lipoproteins. It suggests that the protein is similar to non-specific lipid transporter proteins with anti-fungal activity reported by Bazghaleh et al. [8]. The $24 \mathrm{kDa}$ protein can be related to formation or maintenance of membrane structure of mycorrhizal fungi at inside or around plant roots and protects their hosts from pathogenic fungi.

On the other hand, $53 \mathrm{kDa}$ proteins seem to be expressed only when mycorrhizal fungi and host plants were stressed, because the proteins in T. matsutake had appeared at $4^{\circ} \mathrm{C}$ and $40^{\circ} \mathrm{C}$. Further, the expression of the pro- 
teins in pot-cultured bahiagrass roots may result from water stress in summer. These results suggest that the proteins will be glomalin-like proteins which relieve cells from stresses. Glomalin has been already known as glycoprotein weighs approximately $60 \mathrm{kDa}$ [9], which has similarity to heat shock protein 60 [10].

New creative technique of chromatography developed is very useful for isolation and mass purification of pure $24 \mathrm{kDa}$ protein related to mycorrhizal symbiosis. The protein would contribute to the development of reagents which can detect mycorrhizal fungi by the immunologic analysis. Therefore, sufficient amounts of pure objective protein for building up antibodies are required.

The Diol column has the ability of gel filtration. Thus, our results indicate that MPLC with the Diol column can easily remove ammonium sulfate from large amounts of proteins without conventional dialysis. Moreover, the Diol column in preparative HPLC is effective in isolating single protein from proteins in similar molecular weight under $\mathrm{pH}$ gradient conditions. Except for gel filtration of the Diol column, the column would show positive electric charge of silica residue, since this has small amounts of silica without a Diol group. That is, the $\mathrm{pH}$ gradient method in range of $\mathrm{pH} 7.5$ - 6.5 causes that silica without the Diol group becomes positively charged, so that retention time of each protein is slightly changed. Although the idea of preparative HPLC in gradient methods for proteins had been already reported by Unger et al. [11], the methods have been not utilized. One of the possible reason would be that the $\mathrm{pH}$ range used in their experiments was $\mathrm{pH} 2.0$ - 5.0, so that their methods were usable only for proteins stable at low $\mathrm{pH}$. The fact that the pure protein was isolated at $\mathrm{pH}$ near 7.0 was an advantage of our methods. Further experiments are needed to develop the utility of the Diol column for protein analysis.

Couto et al. [12] have reported that it is difficult to purify proteins from AMF and plants. One of their insistent reasons were difficulty of removing non-protein compounds in plants or fungal tissues. In this investigation, however, these compounds were easily removed from crude proteins by MPLC with the Diol column, and large amounts of the objective proteins were isolated and purified from the crude proteins by gradient preparative HPLC with the Diol column.

AMF are the most important mycorrhizal fungi, because the AMF can colonize almost all of the plants. However, it is very difficult to clarify AMF symbiosis using genome sequence, since it is known that the nuclei of AMF are multiform [1]-[3]. Therefore, proteomic approach of mycorrhizal symbiosis is needed. The new chromatographical techniques developed will greatly contribute to the proteomic approach. In particular, this preparative chromatography would create a new path to analyze proteomically mycorrhizal symbiosis in vitro using the axenic culture of AMF [13] [14].

\section{Conclusion}

In order to develop preparative chromatography for proteomic approach of mycorrhizal symbiosis, MPLC and gradient preparative HPLC with the Diol column were very useful for mass purification of proteins related to mycorrhizal symbiosis, such as 24 and $53 \mathrm{kDa}$ proteins. The $53 \mathrm{kDa}$ proteins would be restrictively expressed under stress conditions, but the $24 \mathrm{kDa}$ proteins were usually detected in all kinds of mycorrhizal fungi. These chromatographical techniques will serve mycorrhizal studies as well as other proteomic studies.

\section{Acknowledgements}

We are grateful to Dr. Chantal Hamel of Saskatchewan University for providing us with soybean seeds and roots.

\section{References}

[1] Tisserant, E., et al. (2013) Genome of an Arbuscular Mycorrhizal Fungus Provides Insight into the Oldest Plant Symbiosis. Proceedings of the National Academy of Sciences of the United States of America, 110, 20117-20122. http://dx.doi.org/10.1073/pnas.1313452110

[2] Ishii, T., Matsubara, T., Yoneda, M. and Cruz, A.F. (2011) Arbuscular Mycorrhizal Fungi Increase Their Diversities by Taking Away Cell Nuclei from Plant Hosts. Horticulture Research (Japan), 10, 59.

[3] Krüger, M., Kruger, C., Walker, C., Stockinger, H. and Schußler, A. (2012) Phylogenetic Reference Data for Systematics and Phytotaxonomy of Arbuscular Mycorrhizal Fungi from Phylum to Species Level. New Phytologist, 193, 970-984. http://dx.doi.org/10.1111/j.1469-8137.2011.03962.x

[4] Ishii, T., Ikeda, T., Rutto, K.L., Cruz, A.F., Matsumoto, I. and Kadoya, K. (1999) Proteins Related to the Mechanism 
of Symbiosis between Vesicular-Arbuscular Mycorrhizal Fungi and Plants. Journal of Japanese Society of Horticultural Science, 68, 229.

[5] Matsubara, T., Yoneda, M. and Ishii, T. (2012) Fungal Isolate “KMI” Is a New Type of Orchid Mycorrhizal Fungus. American Journal of Plant Science, 3, 1121-1126. http://dx.doi.org/10.4236/ajps.2012.38135

[6] Shannon, L.M., Kay, E. and Lew, J.Y. (1966) Peroxidase Isozymes from Horseradish Roots. 1. Isolation and Physical Properties. Journal of Biological Chemistry, 241, 166-2172.

[7] Laemmli, U.K. (1970) Cleavage of Structural Proteins during the Assembly of the Head of Bacteriophage T4. Nature, 227, 680-685. http://dx.doi.org/10.1038/227680a0

[8] Bazghaleh, N., Hamel, C., Knight, J.D., Gan, Y., Vujanovic, V., Tar'an, B., Cruz, A.F. and Ishii, T. (2012) Phytochemical Regulation of Soil Health Chickpea’s Tool Box. Pulse Cluster Annual Meeting, Niagara Falls, 5-6 November 2012.

[9] Wright, S.F. and Upadhyaya, A. (1996) Extraction of an Abundant and Unusual Protein from Soil and Comparison with Hyphal Protein of Arbuscular Mycorrhizal Fungi. Soil Science, 161, 575-586. http://dx.doi.org/10.1097/00010694-199609000-00003

[10] Gadkar, V. and Rillig, M.C. (2006) The Arbuscular Mycorrhizal Fungal Protein Glomalin Is a Putative Homolog of Heat Shock Protein 60. FEMS Microbiology Letters, 263, 93-101. http://dx.doi.org/10.1111/j.1574-6968.2006.00412.x

[11] Unger, K.K., Janzen, R. and Jilge, G. (1987) Packings and Stationary Phases for Biopolymer Separations by HPLC. Chromatographia, 24, 144-154. http://dx.doi.org/10.1007/BF02688477

[12] Couto, M.S.R., Paulo, E.L., Wipf, D. and Gaudot, E.D. (2013) Proteomic Studies of Arbuscular Mycorrhizal Associations. Advances in Biological Chemistry, 3, 48-58. http://dx.doi.org/10.4236/abc.2013.31007

[13] Ishii, T. and Horii, S. (2007) Culture of Mycorrhizal Fungi. Patent No. 4979551, Japan Patent Office.

[14] Ishii, T. (2014) The Role and Use of Mycorrhizal Fungi. Rural Culture Association, Tokyo. 
Scientific Research Publishing (SCIRP) is one of the largest Open Access journal publishers. It is currently publishing more than 200 open access, online, peer-reviewed journals covering a wide range of academic disciplines. SCIRP serves the worldwide academic communities and contributes to the progress and application of science with its publication.

Other selected journals from SCIRP are listed as below. Submit your manuscript to us via either submit@scirp.org or Online Submission Portal.
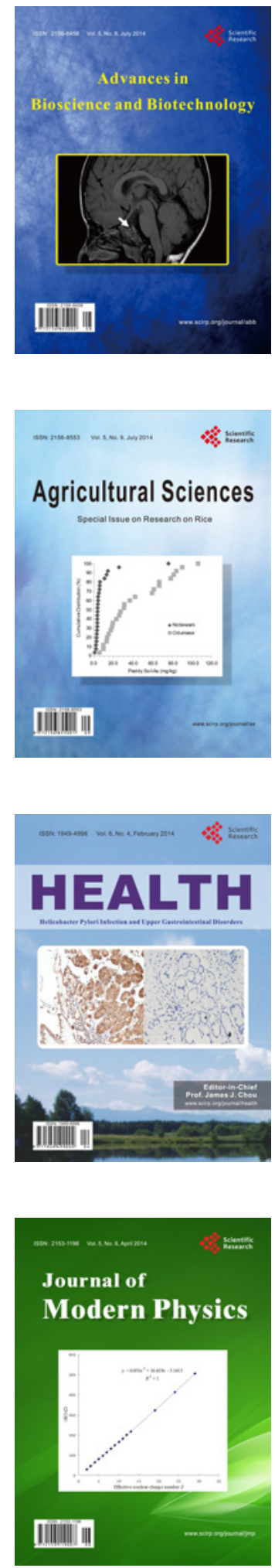
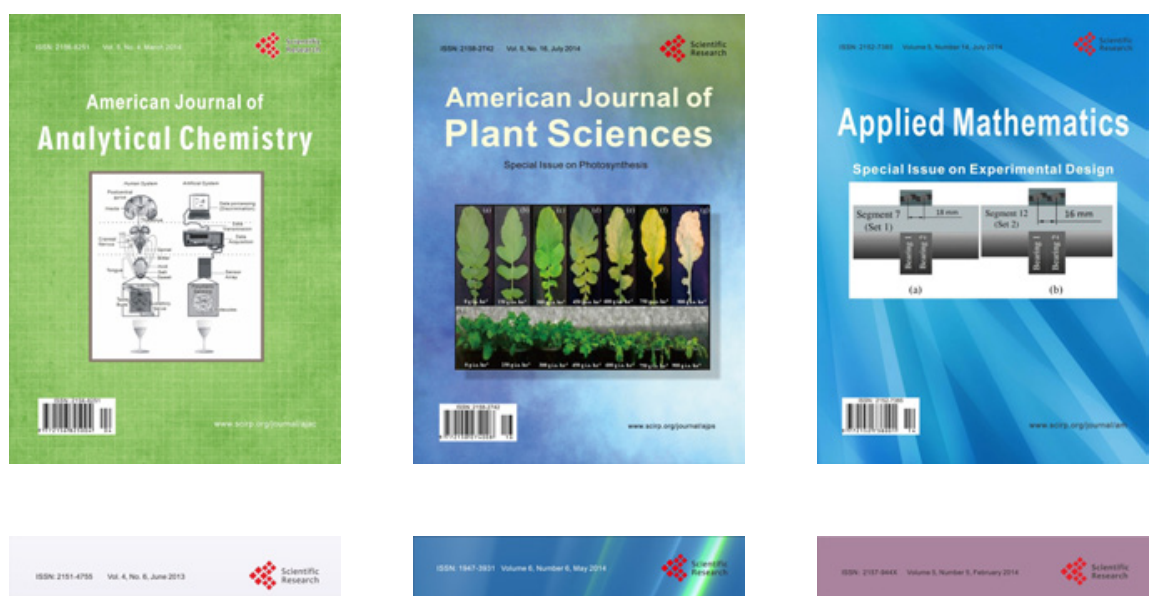

Creative Education
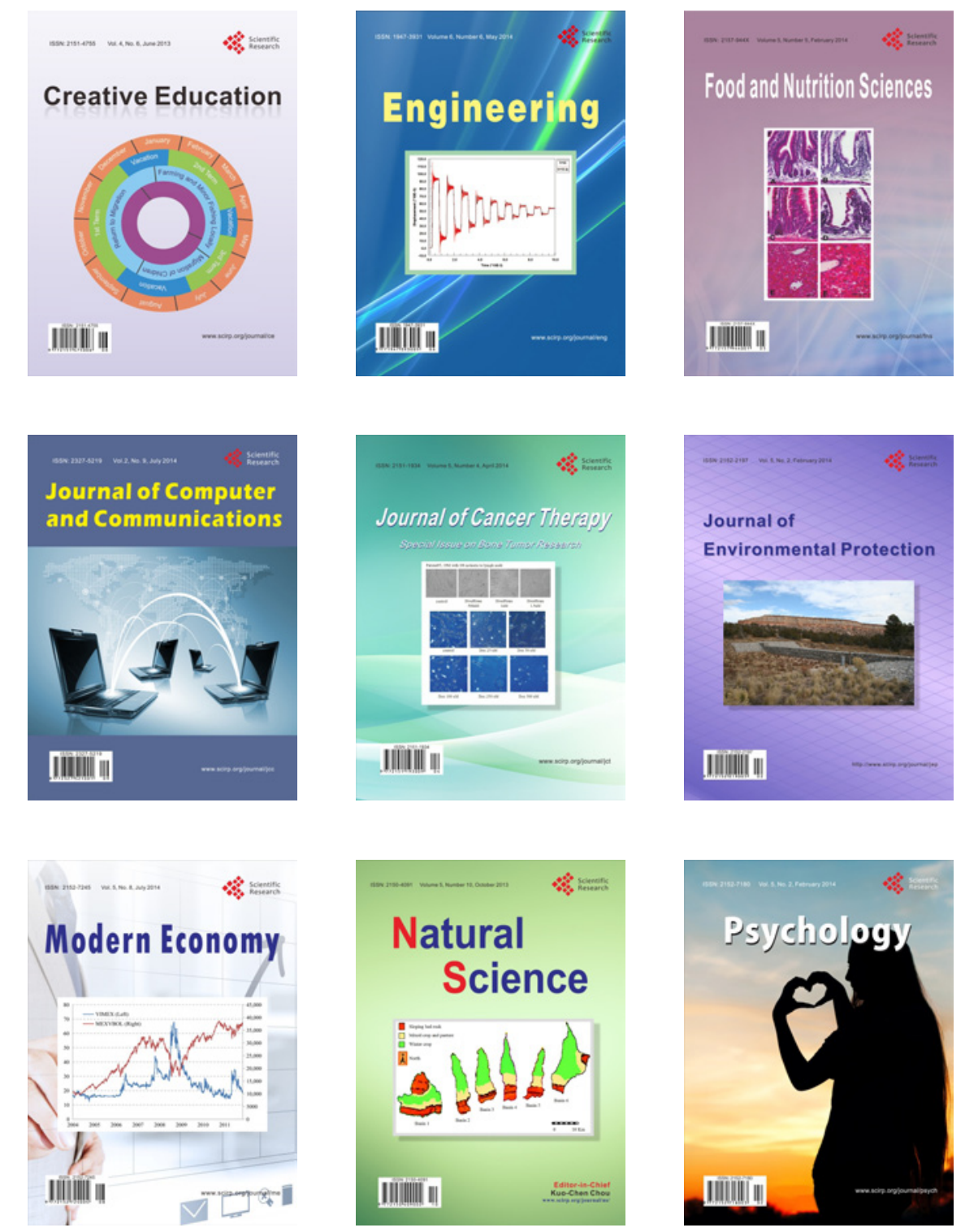